\title{
Correction to: Validity and reliability of a dish-based semi-quantitative food frequency questionnaire for assessment of energy and nutrient intake among Iranian adults
}

\author{
Azam Doustmohammadian ${ }^{1}$, Maryam Amini ${ }^{* *} \mathbb{B}$, Ahmad Esmaillzadeh², Nasrin Omidvar ${ }^{3}$, Mitra Abtahi $^{1}$, \\ Monireh Dadkhah-Piraghaj ${ }^{1}$, Bahareh Nikooyeh ${ }^{1}$ and Tirang R. Neyestani ${ }^{1}$
}

\section{Correction to: BMC Res Notes (2020) 13:95 https://doi.org/10.1186/s13104-020-04944-3} Unfortunately, the authors' final corrections only reached us following the publication of the original article [1].

The below have now been updated in the original article:

1. The word 'and' has been removed from the last sentence of the first paragraph of the 'Introduction.'

2. FFQs has been amended to DFFQs in the last paragraph of the 'Statistical analysis'.

3. FFQ has been amended to DFFQs in the fifth paragraph of the 'Results'.

4. 'On average were correctl classified...' has been amended to 'On average $73 \%$ were correctly classified...' in the sixth paragraph of the 'Results'.

5. The duplicate 'in two ways' has been removed from the first paragraph of the 'Discussion'.

6. The fourth paragraph of the 'Discussion' has been corrected to read: “...The reported correlations are

The original article can be found online at https://doi.org/10.1186/s1310 4-020-04944-3.

*Correspondence: maramin2002@yahoo.com; mamini@sbmu.ac.ir

${ }^{1}$ Department of Nutrition Research, Faculty of Nutrition and Food

Technology, National Nutrition and Food Technology Research Institute,

Shahid Beheshti University of Medical Sciences, No. 7, Hafezi St., Farahzadi

Blvd., P.O.Box: 19395-4741, Tehran 1981619573, Iran

Full list of author information is available at the end of the article similar to those obtained in other similar validation studies. According to a study carried out in Chile the values ranged between 0.26 and 0.47 [35]. In another study in Colombia reported correlations ranged between 0.18 and 0.38 in urban areas and between 0.00 and 0.31 in rural areas [12]..."

7. The title Dr. has been added to the names of Hasan Ein-Zinab, Azadeh Nikoosaleh and Hamid Rasekhi in the 'Acknowledgements' section.

8. Reference 25 has been corrected to read: Amini M, et al. Development of a dish-based semi-quantitative food frequency questionnaire for Iranian population. Med J Islam Repub Iran. in press (accepted 18 Aug 2019).

\footnotetext{
Author details

${ }^{1}$ Department of Nutrition Research, Faculty of Nutrition and Food Technology, National Nutrition and Food Technology Research Institute, Shahid Beheshti University of Medical Sciences, No. 7, Hafezi St., Farahzadi Blvd., P.O.Box: 19395-4741, Tehran 1981619573, Iran. ${ }^{2}$ Department of Community Nutrition, School of Nutritional Sciences and Dietetics, Tehran University of Medical Sciences, Tehran, Iran. ${ }^{3}$ Department of Community Nutrition, Faculty of Nutrition and Food Technology, National Nutrition and Food Technology Research Institute, Shahid Beheshti University of Medical Sciences, Tehran, Iran.
}

Published online: 14 May 2020

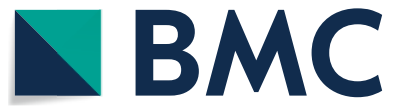

(c) The Author(s) 2020. This article is licensed under a Creative Commons Attribution 4.0 International License, which permits use, sharing, adaptation, distribution and reproduction in any medium or format, as long as you give appropriate credit to the original author(s) and the source, provide a link to the Creative Commons licence, and indicate if changes were made. The images or other third party material in this article are included in the article's Creative Commons licence, unless indicated otherwise in a credit line to the material. If material is not included in the article's Creative Commons licence and your intended use is not permitted by statutory regulation or exceeds the permitted use, you will need to obtain permission directly from the copyright holder. To view a copy of this licence, visit http://creativeco mmons.org/licenses/by/4.0/. The Creative Commons Public Domain Dedication waiver (http://creativecommons.org/publicdomain/ zero/1.0/) applies to the data made available in this article, unless otherwise stated in a credit line to the data. 


\section{Reference}

1. Doustmohammadian A, Amini M, Esmaillzadeh A, Omidvar N, Abtahi M, Dadkhah-Piraghaj M, Nikooyeh B, Neyestani TR. Validity and reliability of a dish-based semi-quantitative food frequency questionnaire for assessment of energy and nutrient intake among Iranian adults. BMC Res Notes. 2020;13:95. https://doi.org/10.1186/s13104-020-04944-3.
Publisher's Note

Springer Nature remains neutral with regard to jurisdictional claims in published maps and institutional affiliations.
Ready to submit your research? Choose BMC and benefit from:

- fast, convenient online submission

- thorough peer review by experienced researchers in your field

- rapid publication on acceptance

- support for research data, including large and complex data types

- gold Open Access which fosters wider collaboration and increased citations

- maximum visibility for your research: over $100 \mathrm{M}$ website views per year

At $\mathrm{BMC}$, research is always in progress.

Learn more biomedcentral.com/submissions 